should at present bo sent. Meetings of the Society have been suspended, but it is hoped to hold the annual general meeting on December 9, at 2 p.m.

\section{Imperial College of Science and Technology}

ThE following Departments of tho Imperial College of Science and Technology will reopen on October 17 for the categories of students mentioned : Engineering, Mathematics, Physics (second and third years and postgraduates); Chemical Engineering, Geology and Oil Technology (third and fourth years and postgraduates); Mining, Mining Geology and Oil Technology (second year). In addition, tho Chemistry Department will open on October 24 for second and third year and postgraduate students, and it is hoped that the postgraduate course in aeronautics may be reopened at an early date. The third and fourth year mining and mining geology students aro at Camborne, and the third and fourth year metallurgy students at Swansea. Such students of biology as can bo accommodated will assemble at the Collego Biological Field Station at Slough. It has not been found possible to continue the first year work leading to the Intermediate B.Sc. and B.Sc.(Eng.).

\section{Colonial Service: Recent Appointments}

THE following appointments and promotions have recently been made in the Colonial Servico: P. A. Gething; agricultural officer, Nigeria; R. Smith, superintendent of agriculture, Gold Coast; W. S. Biggar, veterinary officer, Northern Rhodesia; J. B. Randall, veterinary officer, Uganda; J. I. Taylor, veterinary officer, Northern Rhodesia; D. G. White, veterinary officer, Tanganyika Territory; W. L. Ricketts, personal assistant to the Director of Agriculture and Fisheries, Palestine; G. Griffith, (Chemist, Agricultural Department, Uganda), chemist (soils), Agricultural Department, Straits Settlements and Federated Malay States; U. J. Moffat (agricultural officer), senior agricultural officer, Northern Rhodesia; T. G. Strangeways (superintendent of agriculture, Gold Coast), agricultural officer, Northern Rhodesia; C. B. Bisset (field geologist), senior geologist, Uganda; A. E. P. Kershaw (senior inspector of mines), chief inspector of mines, Federated Malay States; E. B. Thomas (inspector of mines, Nigeria), inspector of mines, Federated Malay States ; R. H. C. Higgins (veterinary officer), senior veterinary officer, Tanganyika Territory; W. Allan (entomologist), assistant director and entomologist, Agricul. tural Department, Northern Rhodesia; IV. A. Macky (formerly meteorological officer, Malaya), meteorologist, Bermuda.

\section{Announcements}

LonD STAMr, chairman of the London Midland and Scottish Railway, and president in 1936 of the British Association, has been appointed adviser on economic co-ordination to a committee of Ministers, under the chairmanship of the Chancellor of the Exchequer, dealing with the co-ordination of departments in relation to economic and financial policy.
Sir Frank Suith, formerly secretary of tho Department of Scientific and Industrial Research, has been appointed director, and Mr. R. S. Whipple, chairman of the board of directors of the Cambridge Instrument Company, Ltd., deputy director, of production of scientific instruments, Ministry of Supply.

Sir Joseph Barcroft, Sir Harold B. Hartley and Sir Frank E. Smith have been appointed members of the Advisory Council to the Committee of the Privy Council for Scientific and Industrial Research. The Right Hon. Lord Cadman and Sir James Jeans have retired from the Council on completion of their terms of office.

ON account of prevailing war conditions, the Council of the Zoological Socicty of Isondon has decided for the present to discontinue the fortnightly scientific meetings.

Dr. Joseri Rigney D'Aunoy, dean and professor of pathology, Louisiana Stato University Medical Centre, New Orleans, has been decorated with the Order of Commendatore of the Crown of Italy in recognition of his achievements in the fields of medical research and education.

ON the recent occasion of the celobration of the Mikado's birthday the Empress of Japan gavo half a million yen for the foundation of a campaign against tuberculosis.

Tre following awards of the North-East Coast Institution of Engineers and Shipbuilders have recently been mado: Institution Shipbuilding and Engineering Gold Meduls to Dr. T. W. F. Brown, of Messrs. R. and W. Hawthorn, Leslie and Co., Ltd., for a paper entitled "Vibration Problems from the Marine Engineering Point of View" (Engineering Medal); NIr. Arnold Emerson, of the William Froudo Laboratory, National Physical Laboratory, for a paper entitled "Special Trials of the Beacon Grange : the Effect of Stecring on Propulsion" (Shipbuilding Medal); M. C. James Memorial Medal to Dr. S. F. Dorey, chief engineer surveyor of Lloyd's Register of Shipping, for a paper entitled, "Strength of Marine Engine Shafting"; R. L. V'eighton Memorial Medal to Johan Boele, student at King's College, Newcastle-upon-Tyne; Institution Scholarship for 1939 (value $£ 100$ ) to William Taylor Atkinson, apprentice of Messrs. Richardsons, Westgarth and Co., Ltd., Hartlepool ; George Mitchell Harroway

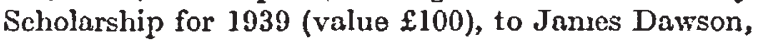
apprentice of Messrs. Smith's Dock Co., Istd., South Bank on Tees.

Erratus. In Nature, October 7, p. 635, col. 2, second line of legend to the graph, for " 1 mol. of $0.1 M$ sugar or ester solution" read " $1 \mathrm{ml}$. of $0.1 M$ sugar or ester solution". 